\title{
Characterizing interactions between surface water and groundwater in the Jialu River basin using major ion chemistry and stable isotopes
}

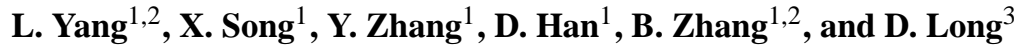 \\ ${ }^{1}$ Key Laboratory of Water Cycle and Related Land Surface Processes, Institute of Geographic Sciences and Natural \\ Resources Research, Chinese Academy of Sciences, 11A, Datun Road, Chaoyang District, Beijing, 100101, China \\ ${ }^{2}$ University of Chinese Academy of Sciences, Beijing, 100049, China \\ ${ }^{3}$ Bureau of Economic Geology, Jackson School of Geosciences, The University of Texas at Austin, Austin, TX 78758, USA \\ Correspondence to: L. Yang (yanglihu@igsnrr.ac.cn), X. Song (songxf@igsnrr.ac.cn)
}

Received: 31 March 2012 - Published in Hydrol. Earth Syst. Sci. Discuss.: 9 May 2012

Revised: 25 October 2012 - Accepted: 25 October 2012 - Published: 20 November 2012

\begin{abstract}
The Jialu River, a secondary tributary of the Huaihe River, has been severely contaminated from major contaminant sources, such as a number of untreated or lightly treated sewage waste in some cities. Groundwater along the river is not an isolated component of the hydrologic system, but is instead connected with the surface water. This study aims to investigate temporal and spatial variations in water chemistry affected by humans and to characterize the relationships between surface water (e.g. reservoirs, lakes and rivers) and groundwater near the river in the shallow Quaternary aquifer. Concentration of $\mathrm{Cl}^{-}$in north Zhengzhou City increased prominently due to the discharge of a large amount of domestic water. Nitrate and potassium show maximum concentrations in groundwater in Fugou County. These high levels can be attributed to the use of a large quantity of fertilizer over this region. Most surface water appeared to be continuously recharged from the surrounding groundwater (regional wells) based on comparison surface water with groundwater levels, stable-isotopes and major ion signatures. However, the groundwater of a transitional well (location SY3) seemed to be recharged by river water via bank infiltration in September 2010. Fractional contributions of river water to the groundwater were calculated based on isotopic and chemical data using a mass-balance approach. Results show that the groundwater was approximately composed of 60 $70 \%$ river water. These findings should be useful for a better understanding of hydrogeological processes at the riveraquifer interface and ultimately benefit water management in the future.
\end{abstract}

\section{Introduction}

The Jialu River (JR), the secondary tributary of the Huaihe River, is severely contaminated by a variety of contaminant sources such as a large number of trade waste and the untreated or lightly treated sewage waste in some cities (Zhang et al., 2009). These wastes have resulted in elevated concentrations of chemical oxygen demand (COD) and ammonia nitrogen $\left(\mathrm{NH}_{3}-\mathrm{N}\right)$ in water within the Zhengzhou region ( $\mathrm{Lu}$ et al., 2008) and the lower reaches in the Zhoukou region (Zhao et al., 2005; Xie et al., 2008). Zhang et al. (2009) reported that concentrations of alkylphenols in surface water were more enriched in the lower reaches compared with the upper stream, with the maximum enrichment taking place in the lower reaches of the Zhengzhou urban zone. Zhang et al. (2011) showed elevated concentrations of nonylphenol, octylphenol, and bisphenol A in the JR bed sediment. Some of the elevated concentrations were high enough to result in potential aquatic and human-health problems.

The Jialu River basin (JRB) has been a part of large-scale irrigation in the Huang-Huai-Hai Plain for over half a century. Increasing use of fertilizers in their irrigated farms is likely to affect these aquifers, which support millions of people. In the wide area of JRB, the rural and urban community depends completely on groundwater. Therefore, the study of the mechanism of groundwater recharge is vital for its sustainable use. Groundwater and surface water are not isolated components of the hydrologic system, but instead interact with each other across a variety of physiographic and climatic landscapes (Winter et al., 1998; Woessner, 2000; 


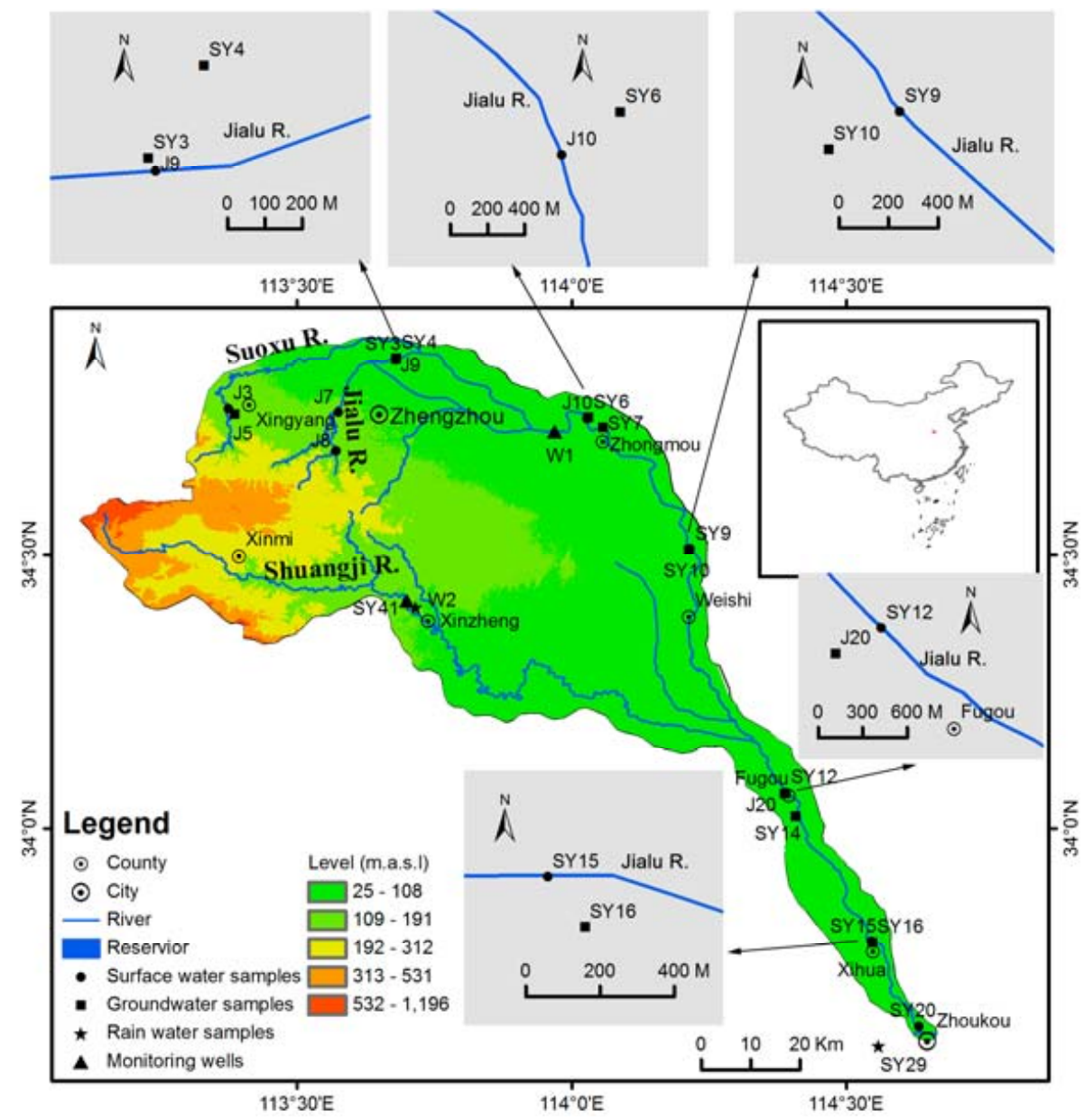

Fig. 1. Study area and relevant sampling locations.

Winter, 2001; Sophocleous, 2002). Thus, there is a noteworthy concern that the trace elements in the water and sediment of JR could contaminate the JRB aquifer. Temporal variations in groundwater chemistry in response to changes in river chemistry and stream flow are also of great concern. A better understanding of the interactions between the two water bodies is a key for effective management of water resources over this region. However, the published studies did not seem to have adequately addressed these issues.

This paper detailed a groundwater-surface water interaction study on the Jialu River. Specific objectives of this study were to (1) investigate temporal and spatial variations in water chemistry in surface water and groundwater affected by humans; and (2) characterize relationships between surface water and groundwater along the JR. This study was conducted on two general scales: (1) a detailed study of the $\mathrm{JR}$ and the surrounding JRB aquifer up to $1190 \mathrm{~m}$ from the river according to two field campaigns in July and September 2010, respectively; and (2) a reconnaissance study of the entire JRB aquifer to provide a hydrogeologic framework and comparison groundwater levels with river water levels using primarily existing data to better understand the interaction.

\section{Study area}

The JRB covers an area of of $2750 \mathrm{~km}^{2}$, ranging in latitude between $33^{\circ} 37^{\prime} 47^{\prime \prime}$ and $34^{\circ} 53^{\prime} 50^{\prime \prime} \mathrm{N}$ and in longitude between $113^{\circ} 6^{\prime} 17^{\prime \prime}$ and $114^{\circ} 38^{\prime} 7^{\prime \prime}$ E (Fig. 1). As a secondary tributary of the Huaihe River, the JR is $220 \mathrm{~km}$ long, originating from Shenshuiyu of Xinmiin in Henan Province. In its source region, the river flows northeaster into Xinmi and Zhengzhou. From Zhengzhou, the river has two abrupt turns, i.e. flowing first east and then southeast through Weishi, Fugou, and Xihua counties, and lastly joining in the Yinghe River at Zhoukou. The main Jialu River channel is contributed by several tributaries. The main tributaries include the Suoxu River, Dongfengqu and Shuangji River.

The climate throughout the study area is with warm, moist summers and cool, dry winters. The average annual temperature in Zhengzhou is $14.4^{\circ} \mathrm{C}$, and the maximum is observed in July with extreme value of $43^{\circ} \mathrm{C}$ and minimum 


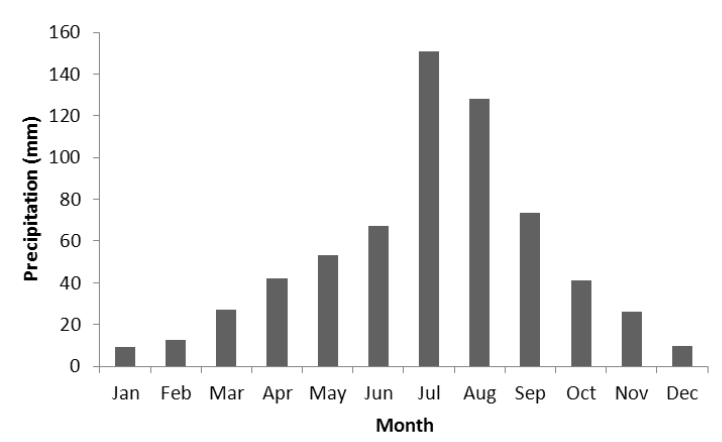

Fig. 2. Monthly precipitation in Zhengzhou.

in February of $-17.9^{\circ} \mathrm{C}$ between 1951 and 2010 . The mean annual precipitation in Zhengzhou is $641 \mathrm{~mm}$ per year from 1951 to 2010, with large interannual variability from a minimum $381 \mathrm{~mm}$ to a maximum $1041 \mathrm{~mm}$. Most of the precipitation falls in the form of rain during the 4-month period from June to September, i.e. the flood season of the river basin, when precipitation accounts for more than $65 \%$ of annual precipitation (Fig. 2). The mean annual potential evaporation is $1910 \mathrm{~mm} \mathrm{yr}^{-1}$ (from 1955 to 2001) at Zhengzhou station, which far exceeds rainfall for the area. Potential evaporation is lowest from December to January $\left(64-72 \mathrm{~mm} \mathrm{month}^{-1}\right)$ and highest from May to June (245-275 $\mathrm{mm} \mathrm{month}^{-1}$; data from China Meteorological Data Sharing Service System, http://cdc.cma.gov.cn/).

The geology of the study area is relatively complex (Fig. 3). The study area pertains to one of the transitional areas between the mountains in the west and the plains in the east. The upper reaches of the JRB are dominated by Paleoproterozoic quartzite and schist and Cambrian sedimentary rocks (i.e. sandstone, limestone, shale, and mudstone). The lower reaches are composed mainly of Holocene alluvium, aeolian deposit and Pleistocene lacustrine-alluvium, alluvium-diluvium, and slope-diluvium sediments (clay, silt sand, fine sand, sand and gravel; data from National Geological Archives of China, website: http://www.ngac.cn).

Regional shallow groundwater levels have been compiled by Yang (2012; based on measurements made in December 1973; Fig. 4). The groundwater levels indicate that groundwater movement has been primarily oriented southwest to northeast in the upstream part and northwest to southeast in the center of the basin (Fig. 4). The highest hydraulic head in the shallow aquifer is in the NW area (122 m a.s.l.), while the lowest ( $42 \mathrm{~m}$ a.s.l.) is in the most southeastern part of the study area (Fig. 4). The static water level ranges between $98 \mathrm{mb}$ b.g.s. (below ground surface) in the northwest to about $4 \mathrm{~m}$ in the southeast parts. The inferred flow lines roughly parallel the Jialu River or Shuangji River.
Table 1. The information of groundwater wells.

\begin{tabular}{lrr}
\hline Name & $\begin{array}{r}\text { Approximate } \\
\text { distance } \\
\text { from river }\end{array}$ & $\begin{array}{r}\text { Depth } \\
\text { of well }\end{array}$ \\
& $\mathrm{m}$ & $\mathrm{m}$ \\
\hline J5 & 570 & 50 \\
SY3 & 30 & 28 \\
SY4 & 230 & 20 \\
SY6 & 170 & 38 \\
SY7 & 380 & 25 \\
SY10 & 590 & 16 \\
J20 & 310 & 14 \\
SY14 & 1190 & 9 \\
SY16 & 70 & 9 \\
W1 & 200 & 6.2 \\
W2 & 300 & 44.4 \\
\hline
\end{tabular}

\section{Methods}

\subsection{Data collection}

The historical precipitation, shallow groundwater and surface water level data were collected from Annual Hydrological Report of the People's Republic of China. In this study, the precipitation and surface water levels were measured daily from Zhongmou and Xinzheng gauging station in the Jialu River basin. The groundwater levels corresponding to the surface water were measured at two monitoring wells (Fig. 1) over the period 1972-1973. The two monitoring wells were located at Zhongmou site (W1) and Xinzheng site (W2), 300 and $200 \mathrm{~m}$ distances from the river gauging station, respectively (Table 1). The manual measurement frequency was six times per month.

\subsection{Water sampling}

Two major sampling campaigns were carried out along the JR and surrounding JRB aquifer up to $1.5 \mathrm{~km}$ from the river in July and September 2010, respectively. The first campaign was during the flood event. Water samples were taken in upstream of Zhengzhou before it rained. The rest samples were collected after it rained. The rainfall amount was up to $102 \mathrm{~mm}$ in $24 \mathrm{~h}$. The JR rose quickly from a low flow stages to a high stage. The river water SY9 and SY20 had been sampled when flood peak did not reach the locations (Table 2). However, river water (location J10, SY12, and SY15) had been sampled when flood peak passed. Besides, two rain water samples (Table 3) were collected at Zhoukou (location SY29) and Xinzheng (location SY41) in the first campaign after the flood event (22-23 July 2010). The second campaign was conducted from 8 to 10 September 2010. A $121.6 \mathrm{~mm}$ rainfall was observed between 5 and 7 September 2010 , i.e. the second campaign was carried out after flooding event. 


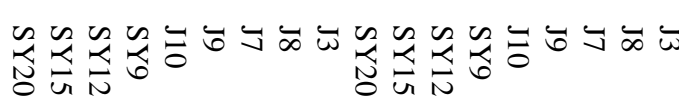

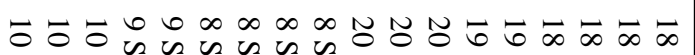

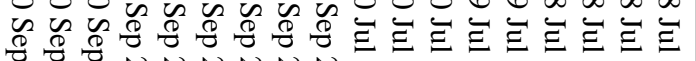
N N N

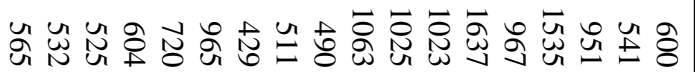

U్N

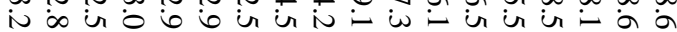

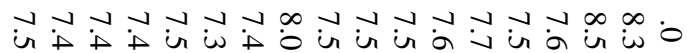

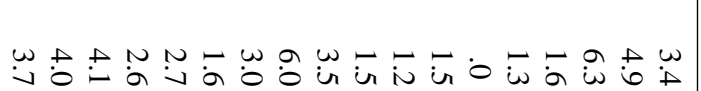

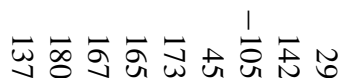

i i $\rightarrow$ N 0 i

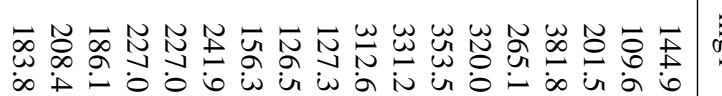

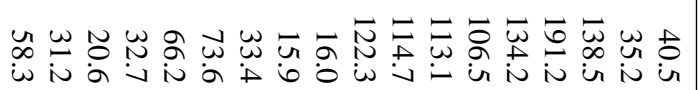

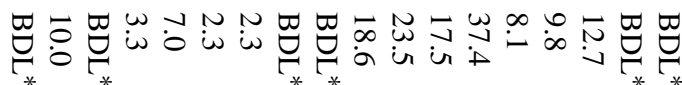

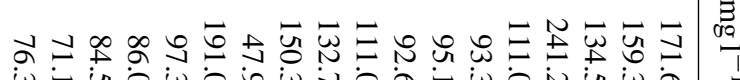

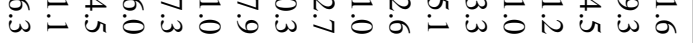

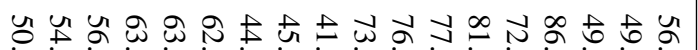

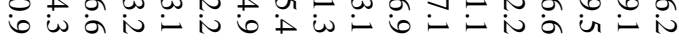

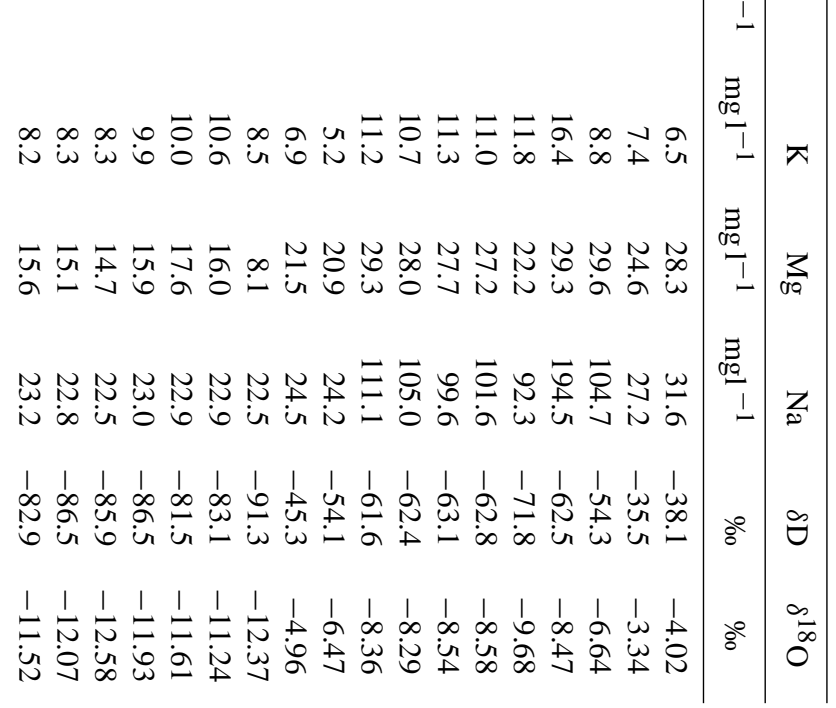


Table 3. Major ions and stable isotope concentrations in rain water in July 2010.

\begin{tabular}{|c|c|c|c|c|c|c|c|c|c|c|c|c|c|c|}
\hline Name & Date & $\begin{array}{c}\text { EC } \\
\mu \mathrm{S} \mathrm{cm}^{-1}\end{array}$ & $\begin{array}{l}{ }^{\mathrm{T}} \\
{ }^{\circ} \mathrm{C}\end{array}$ & $\mathrm{pH}$ & $\begin{array}{l}\mathrm{HCO}_{3} \\
\mathrm{mg} \mathrm{l}^{-1}\end{array}$ & $\begin{array}{c}\mathrm{Cl} \\
\mathrm{mg} \mathrm{l}^{-1}\end{array}$ & $\begin{array}{c}\mathrm{NO}_{3} \\
\mathrm{mg} \mathrm{l}^{-1}\end{array}$ & $\begin{array}{r}\mathrm{SO}_{4} \\
\mathrm{mg} \mathrm{l}^{-1}\end{array}$ & $\begin{array}{r}\mathrm{Ca} \\
\mathrm{mg}^{-1}\end{array}$ & $\begin{array}{c}\mathrm{K} \\
\mathrm{mg} \mathrm{l}^{-1}\end{array}$ & $\begin{array}{c}\mathrm{Mg} \\
\mathrm{mg} \mathrm{l} \mathrm{l}^{-1}\end{array}$ & $\begin{array}{c}\mathrm{Na} \\
\mathrm{mg} \mathrm{l}^{-1}\end{array}$ & $\begin{array}{l}\delta \mathrm{D} \\
\% o\end{array}$ & $\begin{array}{c}\delta^{18} \mathrm{O} \\
\% o\end{array}$ \\
\hline SY29 & $22 \mathrm{Jul} 2010$ & 40.3 & 28.3 & - & 18.6 & 1.6 & 0 & 11.5 & 7.3 & 4.4 & 0.8 & 1.6 & -88.1 & -12.07 \\
\hline SY41 & $23 \mathrm{Jul} 2010$ & 26.3 & - & 8.60 & 24.7 & 7.7 & 0 & 5.3 & 10.6 & 1.3 & 1.8 & 0.5 & -112.2 & -15.57 \\
\hline
\end{tabular}

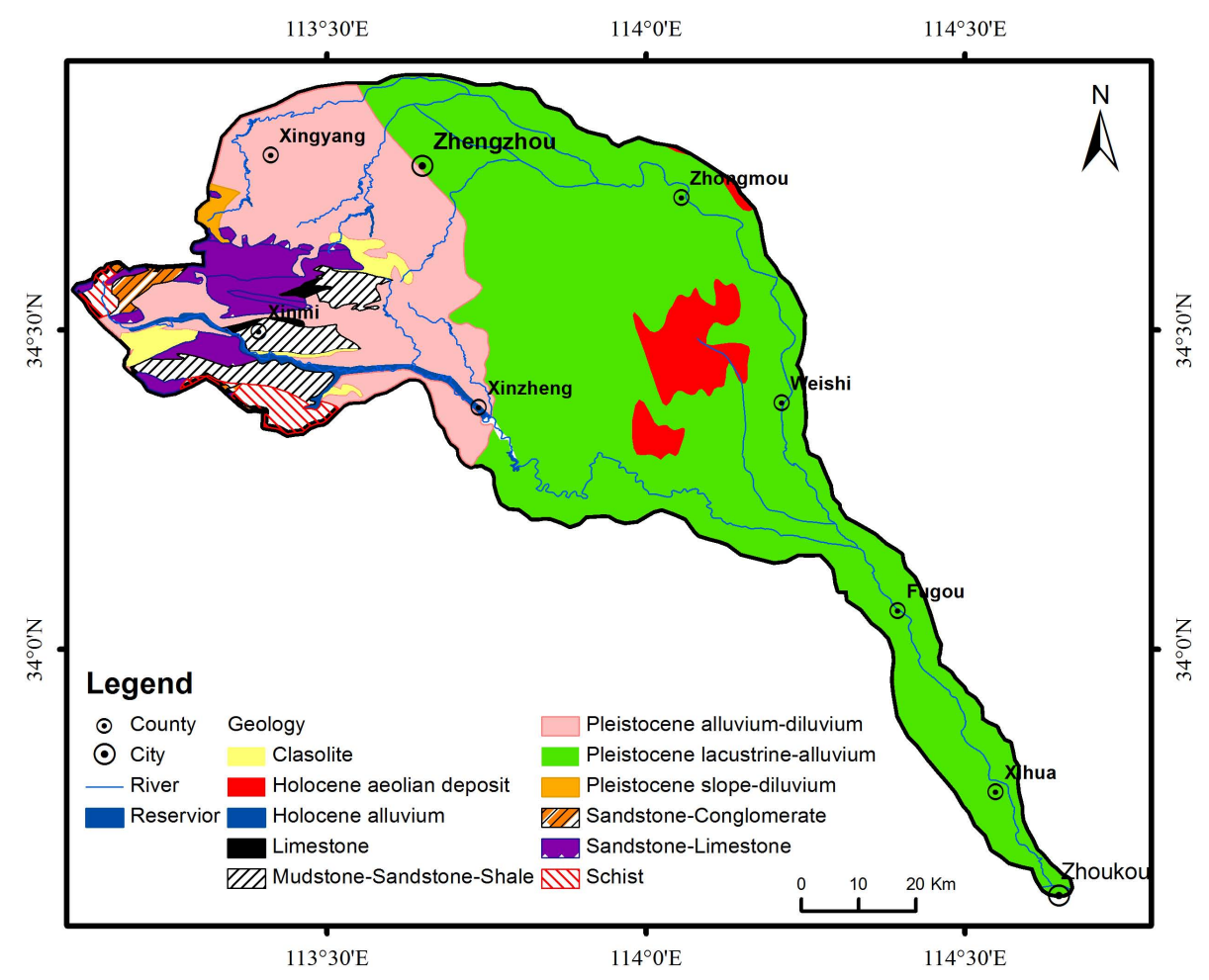

Fig. 3. Major geological formation of the study area (data source: http://www.ngac.cn).

Surface water samples were collected at nine locations (Fig. 1). The groundwater samples were taken from 9 domestic wells in the Quaternary aquifer (Table 4). The depths of the wells ranged between $9 \mathrm{~m}$ (location SY14 and SY16 in Fig. 1) in Fugou and Xihua counties, and $50 \mathrm{~m}$ (location J5 in Fig. 1) in Xingyang, the northwestern part of the investigated area where the surface elevation is approximately $156 \mathrm{~m}$ with reference to the sea level.

Surface water samples were typically collected at bridges in the reaches at a depth of about $30 \mathrm{~cm}$ using a weighted polyethylene water collector. The existing village-supply wells were selected for sampling groundwater. The $100 \mathrm{ml}$ polyethylene bottles used to store the unfiltered stream samples were pre-rinsed with sample water three times before the final water sample was acquired. All samples were sealed with adhesive tape so as to prevent evaporation. The global positioning system (GPS) was used to locate the sampling locations.

\subsection{Water analysis}

Temperature, $\mathrm{pH}$ value and electrical conductivity of each sample were measured in situ using an EC/pH meter (WM22EP, Toadkk, Japan). Oxygen concentration and redox potential were also determined using a Hach HQ30d SingleInput Multi-Parameter Digital Meter. The field water quality parameters were monitored until these values were stabilized.

The water quality was measured at the Center for Physical and Chemical Analysis of Institute of Geographic Sciences and Natural Resources Research, Chinese Academy of Sciences (IGSNRR, CAS). All samples were analyzed for major ion composition, including $\mathrm{Ca}^{2+}, \mathrm{Mg}^{2+}, \mathrm{Na}^{+}, \mathrm{K}^{+}$, $\mathrm{SO}_{4}^{2-}, \mathrm{NO}_{3}^{-}$, and $\mathrm{Cl}^{-}$. Major cations were determined using an inductively coupled plasma optical emission spectrometer (ICP-OES), while major anions were determined using ion chromatography (LC-10A, Shimadzu, Japan). $\mathrm{HCO}_{3}^{-}$was measured by the diluted vitriol-methylic titration method using $0.0112 \mathrm{M} \mathrm{H}_{2} \mathrm{SO}_{4}$. 


\begin{tabular}{|c|c|}
\hline 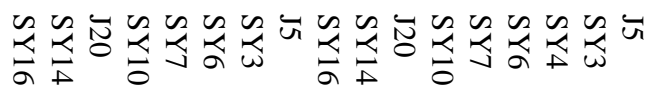 & $\underset{\overparen{O}}{Z}$ \\
\hline 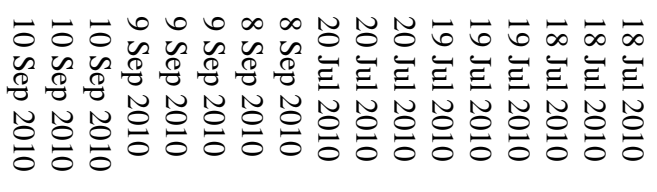 & $\underset{\stackrel{\varpi}{\sigma}}{\forall}$ \\
\hline 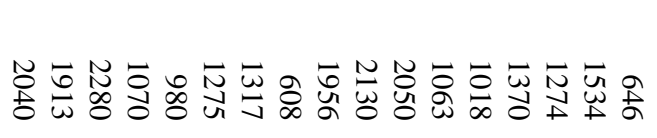 & 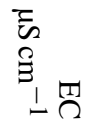 \\
\hline 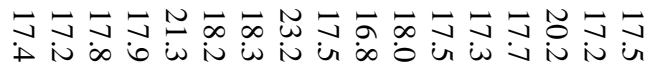 & $\rightarrow$ \\
\hline 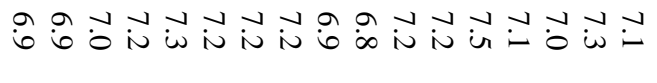 & $\vec{I}$ \\
\hline 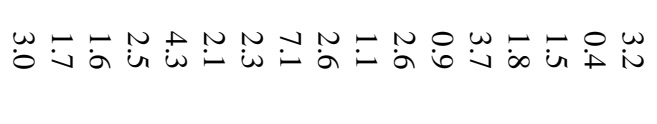 & \\
\hline 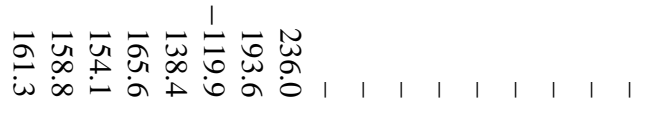 & $\underset{\nu}{0}$ \\
\hline 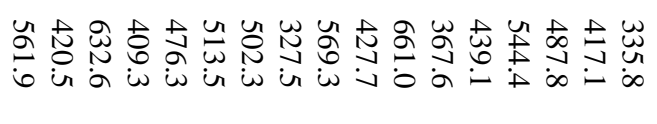 & 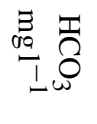 \\
\hline 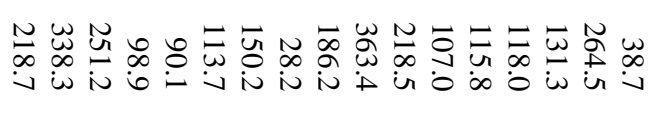 & $\stackrel{1}{1}$ \\
\hline 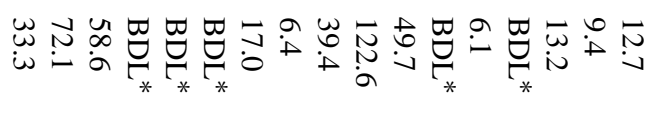 & 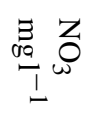 \\
\hline 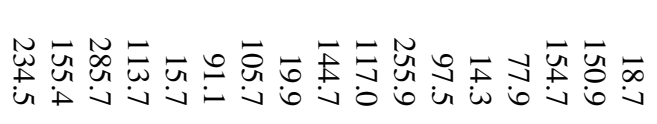 & 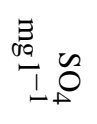 \\
\hline 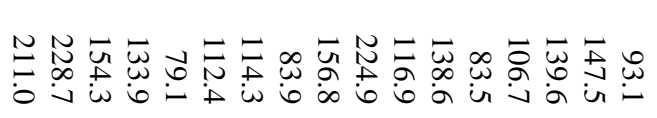 & 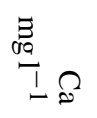 \\
\hline 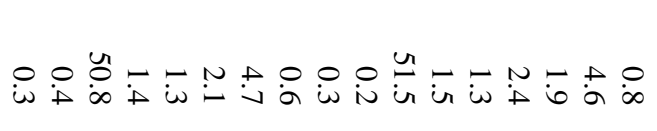 & 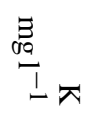 \\
\hline 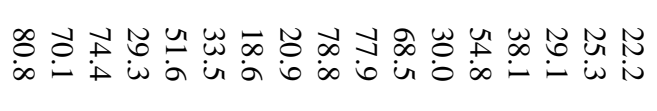 & 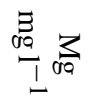 \\
\hline 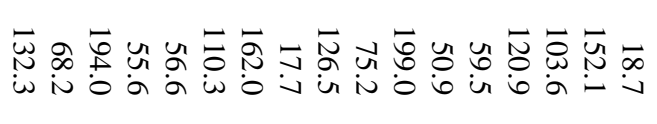 & 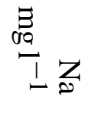 \\
\hline 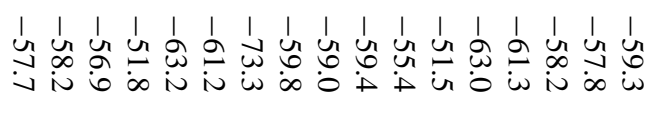 & $a^{Q} \theta$ \\
\hline 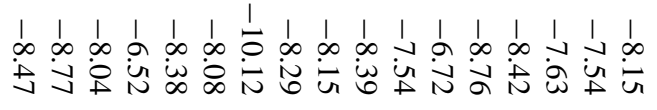 & $\sin ^{\infty}$ \\
\hline
\end{tabular}




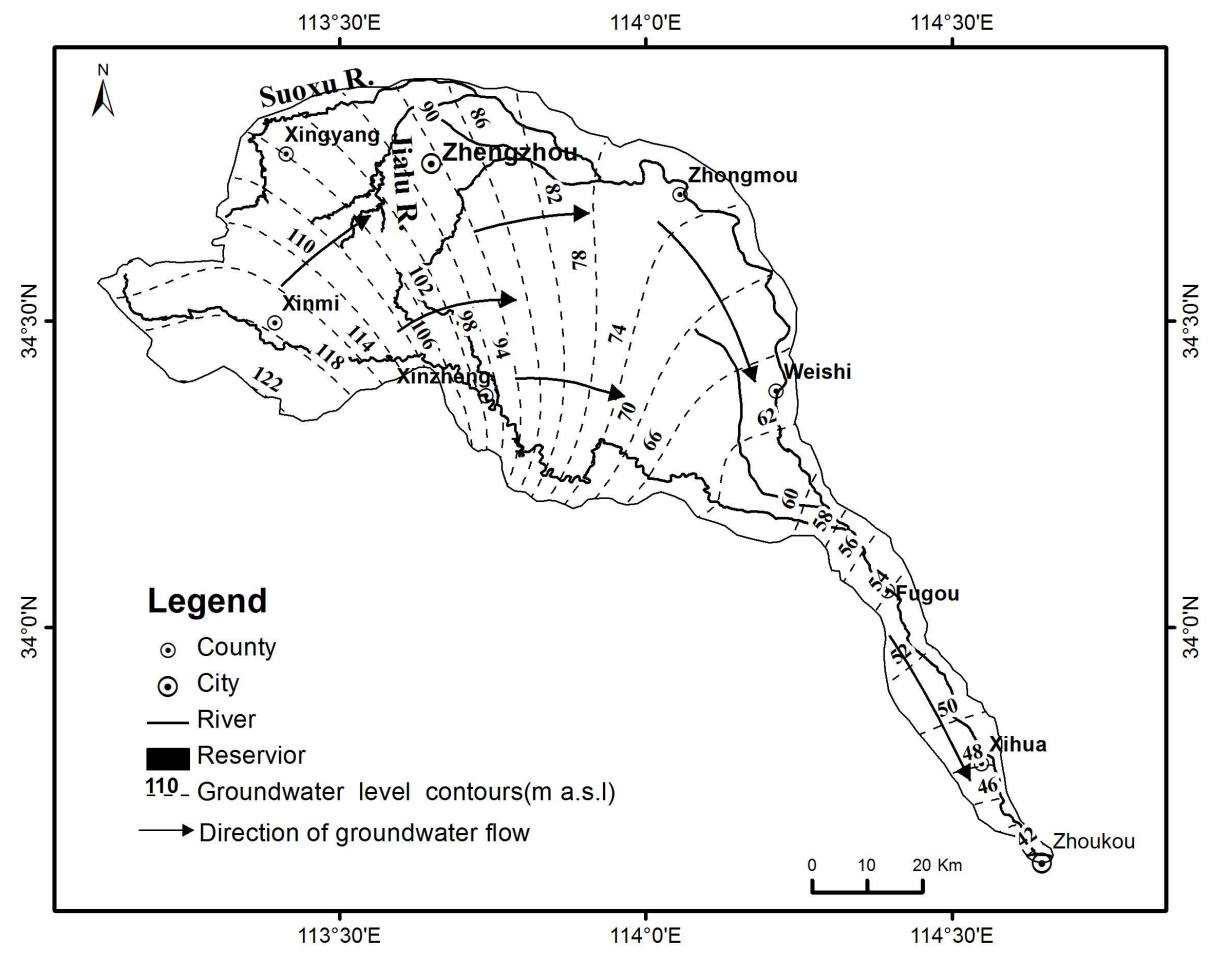

Fig. 4. Shallow groundwater levels in the Jialu River basin based on original source (Yang, 2012). The groundwater level contours (m a.s.1.) are presented at uneven intervals. Arrows indicated the general groundwater flow.

The normalized inorganic charge balance, NICB, defined as $\left(\mathrm{TZ}^{+}-\mathrm{TZ}^{-}\right) / \mathrm{TZ}^{+}$, represents the deviation extent between the total cations and total anions (Edmond et al., 1995; Huh et al., 1998). It was indicated by Huh et al. (1998) that the measured major ions $\left(\mathrm{Ca}^{2+}, \mathrm{Mg}^{2+}, \mathrm{Na}^{+}, \mathrm{K}^{+}, \mathrm{SO}_{4}^{2-}, \mathrm{NO}_{3}^{-}\right.$, $\mathrm{Cl}^{-}, \mathrm{HCO}_{3}^{-}$) are generally in the charge balance. A few of these water samples showed a charge imbalance with a positive charge excess, or some inversely with a negative charge surplus. The positive charge excess could be related to the fact that no analysis of $\mathrm{PO}_{4}^{3-}$ was made and the negative charge surplus could be attributable to the lack of $\mathrm{NH}_{4}^{+}$ measurements. However, the chemical analysis results were adopted when the charge-balance error was within $\pm 10 \%$ in the study.

Water isotopes ( $\delta \mathrm{D}$ and $\delta^{18} \mathrm{O}$ ) were determined at IGSNRR, CAS using off axis integrated-cavity output laser spectroscopy (Model DLT-100; LosGatos Research Inc.) and the method described in Lis et al. (2008). All samples were normalized to internal laboratory water standards that were previously calibrated relative to the Vienna Standard Mean Ocean Water (VSMOW, 0\%o). Results were expressed as parts per thousand deviations from the VSMOW with analytical precisions of $\pm 1 \% \circ(\delta \mathrm{D})$ and $\pm 0.15 \% \circ\left(\delta^{18} \mathrm{O}\right)$.

\section{Results}

\subsection{Water level variations}

When the altitude of the river stage is higher than altitudes of groundwater levels in the nearby area, water flows from the river to the aquifer (a losing reach). Conversely, when the altitude of the river stage is lower, water flows from the aquifer to the river (a gaining reach).

At Zhongmou site, the level of the groundwater was higher than that of the river for most of the study period, including the period of the major flood (Fig. 5a). For example, the water table was, on average $1.6 \mathrm{~m}$ higher than the river and up to $3.6 \mathrm{~m}$ during the major flood. However, the groundwater was nearly close to the river at the beginning of the flood season. At the Xinzheng site the level of the groundwater was 5.5-7.2 $\mathrm{m}$ higher than the river level (Fig. 5b).

Overall, the river in this area is probably a "gaining" river for the most of the time. By comparing it to the water level in the Jialu River, it is apparent that the water level responded by an almost $0.7 \mathrm{~m}$ rise to rainfall that was more than $50 \mathrm{~mm}$ at Zhongmou site during the flood season. Diffuse recharge by infiltrating rainfall may explain an essential component of the water table rise. In a word, it is probable that little if any of the Jialu River discharges directly into the regional flow. 

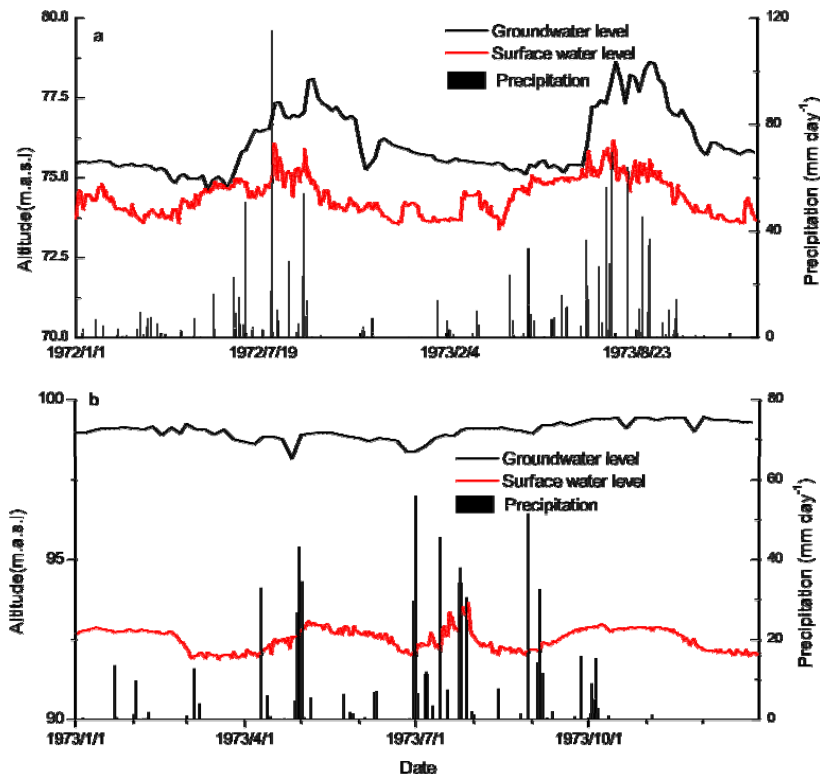

Fig. 5. Comparison of groundwater level with surface water level at Zhongmou (a) and Xinzheng (b). Daily precipitation is plotted in the right $y$-axis. Locations are in shown in Fig. 1.

\subsection{Stable isotopic composition in waters}

Stable isotopic compositions in water can be considered conservative and hardly affected by water-rock reactions under normal temperatures (McCarthy et al., 1992; Gat, 1996). Therefore, isotopic variations may occur within the catchment as a consequence of concentration variations in the input such as rainfall and surface water (Kendall and McDonnell, 1998).

The $\delta \mathrm{D}$ and $\delta^{18} \mathrm{O}$ values of the surface and groundwater samples collected in July and September 2010 were plotted in Fig. 6 with the local meteoric water line (LMWL; precipitation in Zhengzhou; WMO/IAEA, 2010) giving accurate information on the input signal. These samples are well distributed along the LMWL, illustrating that surface and groundwater from the shallow Quaternary aquifer most probably originate from present-day precipitation.

The $\delta^{18} \mathrm{O}$ values varied from $-12.58 \%$ o to $-3.34 \%$, and the $\delta \mathrm{D}$ values changed from $-91.33 \%$ to $-35.48 \%$ in JR water (Table 2). Moreover, heavier isotopes were enriched in river water in the upper reaches, which resulted mostly from evaporation form reservoirs where these samples were collected (Fig. 6).

The two tributaries of Suoxu River and Dongfengqu flow into the JR in north and east Zhengzhou, respectively, and the resulting water sampled downstream (J10) should reflect the mixture of the two channels.

The surface water samples obtained in the second sampling campaign present a wide range of stable isotopic signatures. Isotopic composition of river water was mostly negative. It could be due to precipitation with lighter isotopes.
Signatures of all of these groundwater samples except the sample SY3 remained the same during the flooding event and after the flooding event (Table 4), which indicates that the aquifer seems to be large enough to mask the seasonal isotopic variation caused by rainfall. Sample SY3 was depleted in lighter isotopes after the flooding event, possibly indicating that the riverbank-aquifer water may originate from a mixing of original groundwater and river water with more depleted isotope values.

\subsection{Main geochemical parameters}

Electrical conductivity (EC) (Table 2) measured in surface water varied from 541 to $1637 \mu \mathrm{S} \mathrm{cm}^{-1}$ in July and 429 $965 \mu \mathrm{S} \mathrm{cm}^{-1}$ in September 2010. The former EC reflected the pollutant migration process in the river channel. The high level of EC in location J9 and SY9 was primarily due to samples collected before rain and during the flood peak period. The levels of EC in location J10, SY12 and SY15 were lower than that in location SY9, which is because the flood peak carrying a large amount of pollutant passed. The latter EC values were significantly lower during post-rain conditions, which is likely due to a considerable amount of dilution of ion concentration resulting from heavy precipitation during this period. EC values in groundwater varied from 608 to $2280 \mu \mathrm{S} \mathrm{cm}^{-1}$, with the highest values observed in groundwater from Fugou (sample J20). The water temperature measured in surface water varied from $25.5-29.1^{\circ}$ in July and $22.5-24.5^{\circ}$ in September 2010, which were much higher than the temperature measured in groundwater in both campaigns (16.8 to $21.3^{\circ}$ ). Most of the surface water showed $\mathrm{pH}$ values between 7.0 and 8.0 , whereas groundwater $\mathrm{pH}$ varied between 6.83 and 7.52 with no obvious variation during the campaigns. DO concentrations of the surface water and groundwater ranged from 1.2 to $6.3 \mathrm{mg}^{-1}$ with an averaged concentration of $3.04 \mathrm{mg}^{-1}$ and $0.36-7.09 \mathrm{mg} \mathrm{l}^{-1}$, respectively. Most part of this study area was found to be under oxidizing conditions with Eh values ranging from -119 to $236 \mathrm{mV}$.

The Total Dissolved Solids (TDS) represents the total mineralization (inorganic content) of water and was well correlated with $\mathrm{EC}\left(R^{2}=0.86\right)$, which also reflects the dissolved content in water. TDS values varied between 303.9 (surface waterJ3) and $1385.3 \mathrm{mg} \mathrm{l}^{-1}$ (sample location J20, groundwater in Fugou). The higher mineralization in a natural environment of groundwater generally occurs in water evaporite formations (Petelet-Giraud et al., 2007). The local geological environment is Pleistocene lacustrine-alluvium and contains no evaporate; therefore, it is impossible that the layers studied are influenced by the deep saline groundwater (Han et al., 2002; Gao, 2008). The source of the high dissolved ion content can, therefore, be related to direct or indirect anthropogenic activities that have occurred in cities or counties along the river over the last few decades. 

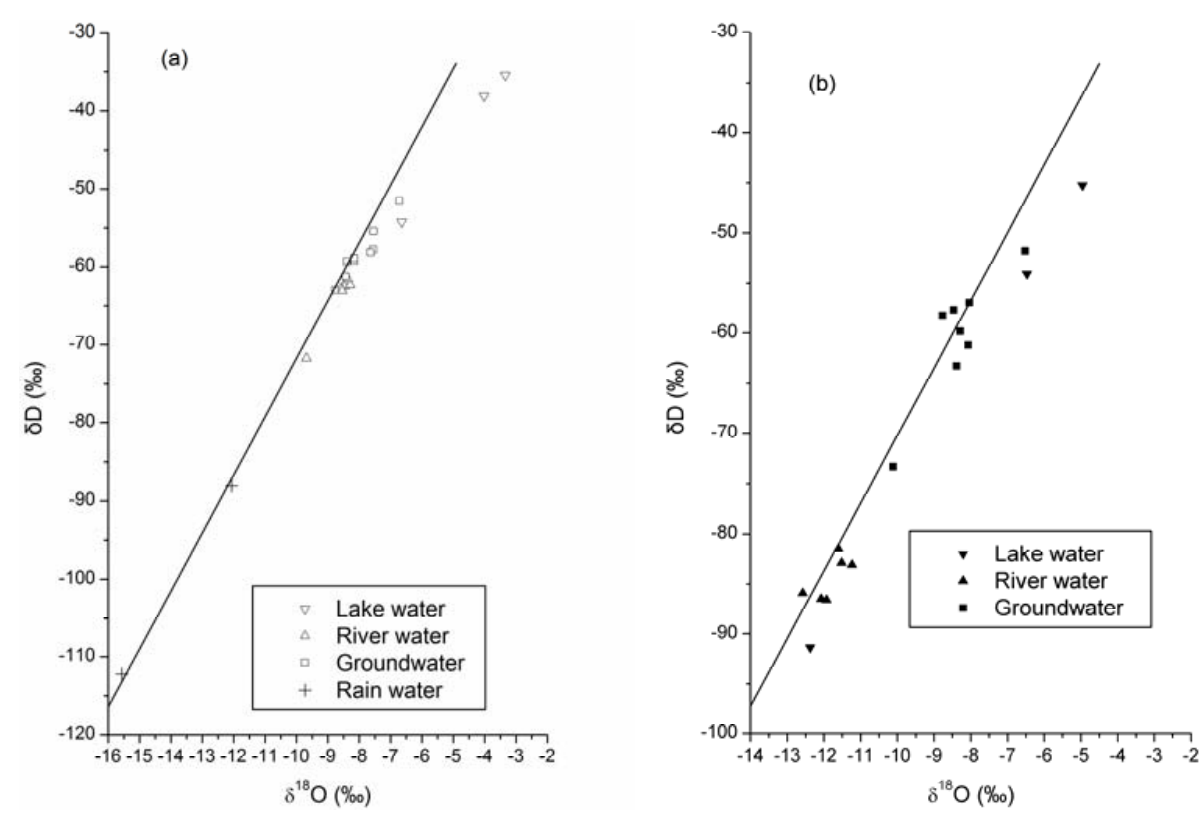

Fig. 6. Relationships between $\delta \mathrm{D}$ and $\delta^{18} \mathrm{O}$ in water collected from JRB in July (a) and September (b) 2010.

Results of chemical analyzes of groundwater and surface water samples are shown in the Piper diagram (Fig. 7). In the upper stream water $(\mathrm{J} 3$ and $\mathrm{J} 8), \mathrm{SO}_{4}^{2-}$ and $\mathrm{Ca}^{2+}$ are the predominant ions, with concentrations ranging from 132 to $172 \mathrm{mgl}^{-1}$ and from 49.08 to $56.17 \mathrm{mg} \mathrm{l}^{-1}$ (Table 2), respectively. Chloride is the second anion after $\mathrm{HCO}_{3}^{-}$over the lower reaches of reservoirs, with the highest concentration being measured in north Zhenghzou during the flooding event (191 $\mathrm{mg} \mathrm{l}^{-1}$, July 2010). There are many possible sources of $\mathrm{Cl}^{-}$, which may be related to untreated or inadequately treated sewage and industrial activities. Sodium is the dominant cation of the river water during the flooding event, varying from 92 to $194 \mathrm{mgl}^{-1}$, whereas, $\mathrm{Ca}^{2+}$ is the dominant cation except for north Zhenghzou after the flooding event, varying from 41 to $63 \mathrm{mg}^{-1}$. It showed most variations in $\mathrm{Cl}^{-}$and $\mathrm{Na}^{+}$content due to anthropogenic influences during the flooding event compared to after the flooding event.

The chemical composition of groundwater at $\mathrm{SY} 3$ varied from $\mathrm{Ca}-\mathrm{Na}-\mathrm{Cl}-\mathrm{HCO}_{3}$ rich in July to $\mathrm{Na}-\mathrm{Ca}-\mathrm{HCO}_{3}$ rich in September 2010. In contrast, the chemical composition of water from other wells did not change significantly during the study period, but the concentrations of major ions varied considerably from well to well. For example, groundwater from the area near the Chulou Reservoir is $\mathrm{Ca}^{2+}$ and $\mathrm{HCO}_{3}^{-}$dominant and is characterized as a $\mathrm{Ca}-\mathrm{Mg}$ $\mathrm{HCO}_{3}$ water type, whereas groundwater in the lower reaches Zhengzhou (SY14) is $\mathrm{Ca}^{2+}$ and $\mathrm{Cl}^{-}$dominant and is characterized as a Ca-Mg-Cl- $\mathrm{HCO}_{3}$ water type. In the groundwater of location $\mathrm{J} 20$, the concentration of $\mathrm{K}^{+}$was as high as $51.49 \mathrm{mg}^{-1}$, which is 32 times higher than the averages of the other groundwater samples. Furthermore, clear

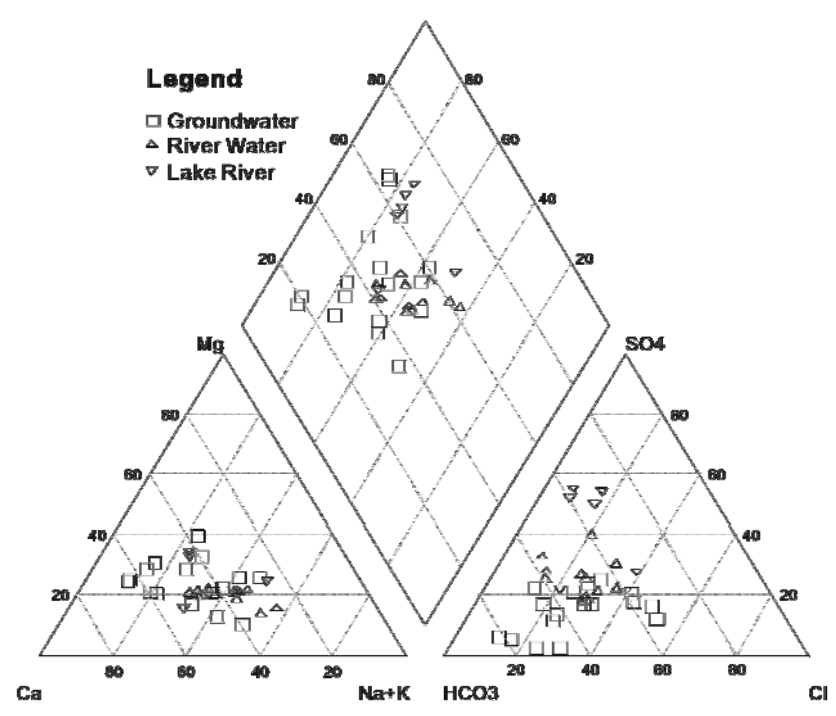

Fig. 7. Piper diagram of major ion chemistry for groundwater, river water and lake water in the study area.

anthropogenic inputs are indicated in groundwater of location SY14 and J20 (Fugou County) where high $\mathrm{NO}_{3}^{-}$contents excess the World Health Organization Standard (WHO, $2008)$ and Chinese limitation value $\left(10 \mathrm{mg}^{-1}\right.$ calculated as $N$ ) for drinking water (Ministry of Environmental Protection, the People's Republic of China, 2002).

The PHREEQC was used to compute the saturation indices (SI). The saturation indices with respect to calcite of surface water are between -0.19 and 0.66 , whereas for groundwater they range from 0.08 to 0.46 (Table 5). 
Table 5. Water saturation indices (SI) with respect to calcite in July and September. The PHREEQC was used to compute the saturation indices.

\begin{tabular}{llr}
\hline SI/calcite & July 2010 & September 2010 \\
\hline \multicolumn{3}{c}{ Surface water } \\
\hline J3 & 0.47 & -0.19 \\
J8 & 0.66 & 0.34 \\
J7 & 1.03 & -0.15 \\
J9 & 0.64 & -0.06 \\
J10 & 0.37 & 0.15 \\
SY9 & 0.65 & 0.12 \\
SY12 & 0.61 & -0.05 \\
SY15 & 0.43 & 0.01 \\
SY20 & 0.46 & -0.01 \\
\hline & Groundwater & \\
\hline J5 & 0.08 & 0.22 \\
SY3 & 0.46 & 0.32 \\
SY4 & 0.25 & 0.33 \\
SY6 & 0.3 & 0.40 \\
SY7 & 0.51 & 0.31 \\
SY10 & 0.28 & 0.29 \\
J20 & 0.37 & 0.21 \\
SY14 & 0.13 & 0.28 \\
SY16 & 0.24 & \\
\hline
\end{tabular}

The surface water showed an oversaturation with respect to calcite $(\mathrm{SI}=0.37 \sim 1.03$; Table 5) during the flooding event, while some of the water was undersaturated (SI $=-0.19 \sim-0.01$; Table 5) after the flooding event. The SI values with respect to calcite indicate that the groundwater is slightly saturated with respect to this solid phase.

\section{Discussion}

\subsection{Anthropogenic sources and impacts on surface water and groundwater}

Human activity is one of the most important factors affecting hydrology and water quality. Water chemistry of rivers can reflect changes in watersheds, making rivers good indicators of land use (Meybeck and Helmer, 1989). Chemical alteration associated with human activity is related to the development of cities and intensification of agriculture, especially the discharge of untreated sewage waste. Therefore, human activities driven by economic development, population growth, and urbanization jointly result in alterations of river water quality.

The average concentration of sulfate was $8 \mathrm{mgl}^{-1}$ in the rain water, which was far less than that of the water in the upper stream. Although the isotope data that were used showed that the lake water was extremely enriched compared to the other water bodies, the increasing of sulfate was

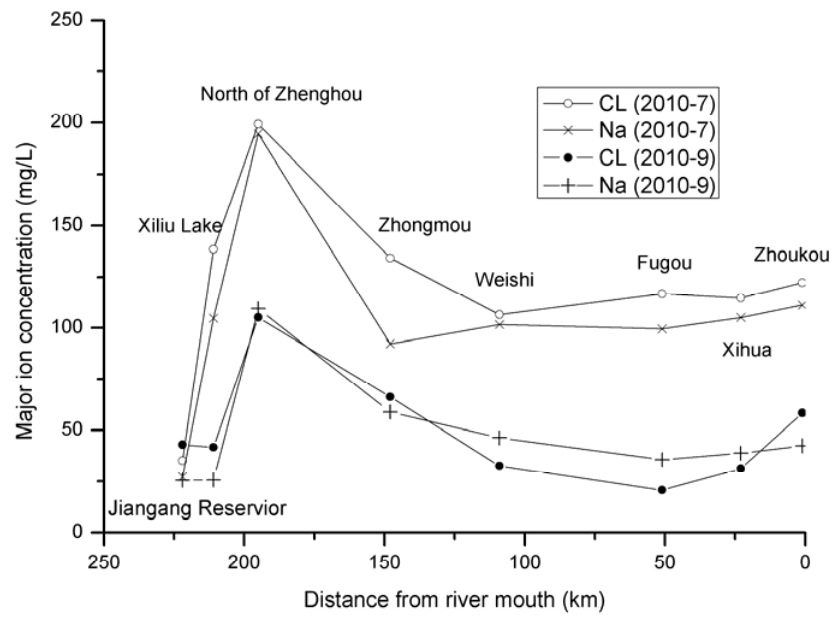

Fig. 8. Major ion concentration/distance from river mouth profiles for chloride and sodium in the main stream of the JR.

out of proportion to the rain. This would make it clear that the source of $\mathrm{SO}_{4}^{2-}$ results from the oxidation of uncovered pyrite in headwater areas of the Suoxu River and JR, considering mining in the upstream mountain area (Pang, 1994). Because the reservoir retains river water, the concentration of $\mathrm{SO}_{4}^{2-}$ is accumulated. Similarly, the average of the concentrations of $\mathrm{Cl}^{-}$and $\mathrm{Na}^{+}$were 4 and $1 \mathrm{mgl}^{-1}$, respectively, which were also less than that of the water in the river. The concentration-river distance profiles (Fig. 8) for the two indicator ions $\left(\mathrm{Cl}^{-}\right.$and $\left.\mathrm{Na}^{+}\right)$show the pronounced effects of urbanization on the major ion chemistry of the JR. Concentration of $\mathrm{Cl}^{-}$is below $30 \mathrm{mgl}^{-1}$ in the upper reaches of Zhengzhou, and then increases by a factor of 4.4 in the urban region of north Zhengzhou. It becomes rapidly diluted over the lower reaches of the city in July. The reason is that Zhengzhou is a big city with a population of $4.3 \times 10^{6}$ people, whereas the lower reaches of counties are relatively small with a population of $0.5-0.8 \times 10^{6}$ people (Henan Provincial Bureau of Statistics, 2011). The untreated sewage waste (average $37 \mathrm{t} \mathrm{day}^{-1}$ between 2007 and 2009) in Zhengzhou was eventually discharged into the Jialu River. Chloride and sodium are major electrolytes in human urine (Kirchmann and Pettersson, 1995) and are therefore concentrated primarily in waste water. The higher $\mathrm{Cl}^{-}$and $\mathrm{Na}^{+}$in the river could be coming from sewage wastes. Trends in $\mathrm{Cl}^{-}$ and $\mathrm{Na}^{+}$after a flooding event are the same as those during the flooding event. However, the concentration after a flooding event is lower than that during the flooding event due to the precipitation.

Among the dissolved solutes, $\mathrm{NO}_{3}^{-}$and $\mathrm{K}^{+}$show maximum concentrations in groundwater in Fugou County. These high nitrate levels can be attributed to agricultural practices in this region, especially artificial and manure fertilization (Zhang et al., 1996; Liu et al., 2005; Ma et al., 2009) and animals feeding. Fugou County is one of the top 
10 counties growing vegetable in China. In 2009, Fugou had 361000 rural employees, a total sown area of $144730 \mathrm{ha}$, and 120099 large animals (Henan Provincial Bureau of Statistics and Henan Survey Office of NBS, 2010). To increase crop yield and income, farmers are currently decreasing the use of organic fertilizer in favor of inorganic fertilizers with proportions of nitrogen, phosphorous, and potassium throughout agricultural regions of Fugou. This approach has led to losses of fertilizer into groundwater. Potassium concentration (J20) largely exceeds the mean potassium concentrations in drinking water, e.g. $2.5 \mathrm{mg} \mathrm{l}^{-1}$ in the UK (Powell et al., 1987) and up to $8 \mathrm{mgl}^{-1}$ in Canada (Health Canada, 2008). Those results are probably caused by the use of a large amount of fertilizer.

\subsection{Interactions between surface water and groundwater}

By synthesizing various types of field data obtained in this study, it is possible to provide a picture of the surface water and groundwater interactions within the basin. Groundwater wells were generally categorized into two groups based on dissolved-solids concentrations and stable isotope values: (1) regional wells, in areas where groundwater did not include water recently recharged from the river (all locations except the SY3 in the basin); and (2) transitional wells, in areas where groundwater was possibly a composite of recharge from the river and water from regional systems during river high flow periods; and was only water from regional systems during river low flow periods (location SY3).

The regional wells ranged from 70 to $1190 \mathrm{~m}$ from the river and had water with a constant stable isotopic signature $\left(\delta \mathrm{D}, \delta^{18} \mathrm{O}\right)$ throughout the hydrological cycle, which did not reflect seasonal variations although the river water isotope varied greatly due to precipitation. This illustrates that the groundwater never or rarely received recharge from surface water. Besides, from a conventional hydrogeological survey and comparison surface water with groundwater levels at two sites it is evident that the groundwater feeds the river, perhaps as a result of infiltration from the rain.

The transitional well of SY3, $30 \mathrm{~m}$ from the river, seemed to be closely connected to the nearest river water as the groundwater had similar trends of stable isotope signatures and chloride content with the river. The salient features of the isotope and hydrochemistry of groundwater at SY3 are as follows. Before the flood event (July 2010), the $\delta \mathrm{D}$ and $\delta^{18} \mathrm{O}$ of water were $-57.80 \%$ and $-7.54 \%$, respectively. After the flood event (September 2010), the $\delta \mathrm{D}$ and $\delta^{18} \mathrm{O}$ was found to be depleted. In the same way, the $\mathrm{Cl}^{-}$content in September 2010, was also diluted. That is because the recharge by river water via bank infiltration in September 2010, could be characterized by lower $\mathrm{Cl}^{-}$and relatively depleted $\delta \mathrm{D}$ and $\delta^{18} \mathrm{O}$ signatures.

The composition of groundwater at SY3 in September 2010 can be described by a mixture of two possible sources, including groundwater from the regional system, and river water. The river water and rainwater sources were combined in one as river water because river floods in September 2010 were mainly from the precipitation.

Although one sample of observation seems to be less than satisfactory in detecting groundwater recharge in flooding events, it can provide information on the fraction of river to groundwater recharge for a specific period of time. When these water sources are considered as end members to the groundwater at SY3, it is possible to estimate mixing proportions between the waters using a mass-balance approach (Christophersen and Hooper, 1992; Clark and Fritz, 1997; Kendall and Mcdonnell, 1998).

Assuming that groundwater at SY3 in September 2010 was a result of mixing original groundwater (GW) and river water (RW), the following equation can be used to assess the fractional contributions of river water to the groundwater:

$f=\frac{C_{\mathrm{S}}-C_{\mathrm{GW}}}{C_{\mathrm{RW}}-C_{\mathrm{GW}}} \times 100 \%$

where $C_{\mathrm{S}}$ is the $\mathrm{Cl}^{-}, \delta \mathrm{D}$ or $\delta^{18} \mathrm{O}\left(\mathrm{mg} \mathrm{l}^{-1}\right.$ or $\%$ o of the mixed water sample (location SY3 in September 2010); $C_{\mathrm{RW}}$ is the $\mathrm{Cl}^{-}, \delta \mathrm{D}$ or $\delta^{18} \mathrm{O}$ of river water (location J9 in September 2010); and $C_{\mathrm{GW}}$ is the $\mathrm{Cl}^{-}, \delta \mathrm{D}$ or $\delta^{18} \mathrm{O}$ of original groundwater in July 2010 that is not influenced by river recharge. Location SY3 in July 2010 was chosen as the original groundwater end-member because it has not recharged by the river.

The resulting fractional contrition percentages are 60 , 61 and $70 \%$ using $\mathrm{Cl}^{-}, \delta \mathrm{D}$ and $\delta^{18} \mathrm{O}$, respectively. Mixing calculations suggest that the groundwater at SY3 in September 2010 was composed of approximately $60-70 \%$ river water, depending on the tracer employed. This result shows that more than half of water contamination of river water can be into the groundwater if the river water is severely polluted.

\section{Conclusions}

The Jialu River basin is being faced with environmental pressures mainly coming from anthropogenic influences. Hence, it is important to systemically monitor the Jialu River and groundwater to provide detailed isotopic and hydrochemical information for a greater understanding of these impacts on the river and groundwater and how to effectively manage of the basin in the future. The study comprised of EC, temperature, $\mathrm{pH}, \mathrm{DO}$, Eh, the isotopes and the major dissolved inorganic ions along the Jialu River in July and September 2010. In addition, existing geological data, precipitation data and surface and groundwater level data were included in the analysis. Major findings are as follows.

1. The concentration of $\mathrm{Cl}^{-}$in north Zhengzhou City significantly increased in river samples during two campaigns conducted due to discharge of a large amount 
of untreated or slightly treated waste water. Nitrate and potassium show maximum concentrations in groundwater in Fugou County. These high levels can be attributed to agricultural practices across this region, especially artificial and manure fertilization and animals feeding.

2. All evidence shows that the surface water appeared to be continuously recharged from the surrounding groundwater (locations J5, SY6, SY7, SY10, J20, SY14 and SY16) throughout the year. In addition, the river was recharged by groundwater at location SY3 in July 2010. The contaminated aquifers discharging to river can result in a long-term contamination of surface water.

3. The transitional well of SY3 seemed to be recharged by river water via bank infiltration in September 2010. Fractional contributions of the river water to the groundwater were calculated based on isotopic and chemical data using a mass-balance approach. The groundwater (SY3 in September 2010) was approximately composed of $60-70 \%$ river water. This finding demonstrates that the river water contamination can be into the groundwater if the river water is severely polluted.

Acknowledgements. The authors are grateful to Major Science and Technology Program for Water Pollution Control and Treatment (Grant No. 2009ZX07210-006) for supporting and financing the research. We would also like to thank Xiting Long (Guilin University of Technology, China), for his assistance in sample collection.

Edited by: A. D. Reeves

\section{References}

Christophersen, N. and Hooper, R. P.: Multivariate analysis of stream water chemical data: theuse of principal components analysis for the end-member mixing problem, Water Resour.Res., 28, 99-107, 1992.

Clark, I. D. and Fritz, P.: Environmental Isotopes in Hydrogeology, Lewis Publishers, New York, 1997.

Edmond, J. M., Palmer, M. R., Measures, C. I., Grant, B., and Stallard, R. F.: The fluvial geochemistry and denudation rate of the Guayana Shield in Venezuela, Colombia, and Brazil, Geochim. Cosmochim. Acta, 59, 3301-3325, 1995.

Gao, S.: Groundwater Cycle Pattern and Renewability Evaluation of Groundwater in the Quaternary aquifer in Henan Plain, Ph.D. thesis, Jilin University, Changchun, 85 pp., 2008.

Gat, J. R.: Oxygen and hydrogen isotopes in the hydrologic cycle, Annu. Rev. Earth Pl. Sc., 24, 225-262, 1996.

Han, X., Wang, X., and Zhou, T.: Analysis of tertiary system water chemical characteristics of Henan plain, J. Jiaozuo Inst. Technol., 21, 357-359, 2002.

Health Canada: Guidance on Potassium from Water Softeners, Health Canada, Ottawa, Ontario, 2008.
Henan Provincial Bureau of Statistics, Henan Survey Office of NBS: 2010 Henan Statistical Yearbook, China Statistics Press, Beijing, 2010.

Henan Provincial Bureau of Statistics: The 6th national population census bulletin and Henan Provincial Bureau of Statistics, Zhengzhou, 2011.

Huh, Y., Tsoi, M., Zaitsev, A., and Edmond, J. M.: The fluvial geochemistry of the rivers of Eastern Siberia: I. tributaries of the Lena River draining the sedimentary platform of the Siberian Craton, Geochim. Cosmochim. Acta, 62, 1657-1676, 1998.

Kendall, C. and McDonnell, J. J.: Isotope Tracers in Catchment Hydrology, Elsevier, Amsterdam, 1998.

Kirchmann, H. and Pettersson, S.: Human urine - chemical composition and fertilizer use efficiency, Nutr. Cycl. Agroecosys., 40, 149-154, 1995.

Lis, G., Wassenaar, L. I., and Hendry, M. J.: High-precision Laser spectroscopy $\mathrm{D} / \mathrm{H}$ and ${ }^{18} \mathrm{O} /{ }^{16} \mathrm{O}$ measurements of microliter natural water samples, Anal. Chem., 80, 287-293,2008.

Liu, A., Ming, J., and Ankumah, R. O.: Nitrate contamination in private wells in rural Alabama, United States, Sci. Total Environ., 346, 112-120, 2005.

Lu, D., Huang, W., Li, X., and Li, J.: Correlation of Zhengzhou City economic development and Jialu River Zhongmouchenqiao section water quality, Henan Sci., 26, 1117-1120, 2008.

Ma, J., Ding, Z., Wei, G., Zhao, H., and Huang, T.: Sources of water pollution and evolution of water quality in the Wuwei basin of Shiyang River, Northwest China, J. Environ. Manage., 90, 11681177, 2009.

McCarthy, K. A., McFarland, W. D., Wilkinson, J. M., and White, L. D.: The dynamic relationship between ground water and the Columbia River: using deuterium and oxygen-18 as tracers, J. Hydrol., 135, 1-12, 1992.

Meybeck, M. and Helmer, R.: The quality of rivers: from pristine stage to global pollution, Palaeogeogr. Palaeocl., 75, 283-309, 1989.

Ministry of Environmental Protection, the People's Republic of China: Environmental Quality Standard for Surface Water, GB 3838-2002, Beijing, 2002.

Pang, C.: Metal and Non-Metallic Mineral in Henan, Henan Education Press, Zhengzhou, 1994.

Petelet-Giraud, E., Negrel, P., Gourcy, L., Schmidt, C., and Schirmer, M.: Geochemical andisotopic constraints on groundwater-surface water interactions in a highly anthropized site, The Wolfen/Bitterfeld megasite (Muldesubcatchment, Germany), Environ. Pollut., 148, 707-717, 2007.

Powell, P., Bailey, R. J., and Jolly, P. K.: Trace Elements in British Tap-Water Supplies, PRD 706-M/1, WRc Enviroment Medmenham Laboratory, Medmenham, 1987.

Sophocleous, M.: Interactions between groundwater and surface water: the state of the science, Hydrogeol. J., 10, 52-67, 2002.

WHO: Guidelines for Drinking-Water Quality, 3rd Edn., Incorporating the First and Second Addenda, Volume 1 Recommendations, Geneva, 2008.

Winter, T. C.: Ground water and surface water: the linkage tightens, but challenges remain, Hydrol. Process., 15, 3605-3606, 2001.

Winter, T. C., Harvey, J. W., Franke, O. L., and Alley, W. M.: Groundwater and Surface Water: a Single Resource, US Geological Survey, Denver, Colorado, 1998. 
WMO/IAEA: Global Network of Isotopes in Precipitation, The GNIP Database, available online at: http://nds121.iaea.org/wiser/ index.php (last access: May 2012), 2010.

Woessner, W. W.: Stream and fluvial plain ground water interactions: rescaling hydrogeologic thought, Ground Water, 38, 423429, 2000.

Xie, D., Zhao, H., Zhai, G., Ouyang, K., Liu, H., and Yang, S.: On the changes of water quality of Jialu River in Zhoukou region, J. Zhoukou Normal Univ., 25, 68-71, 2008.

Yang, L.: Mechanism of Interaction between Groundwater and Surface Water at the Polluted Channel in the Shaying River Basin, $\mathrm{Ph} . \mathrm{D}$. thesis, Graduate University of Chinese Academy of Sciences, Beijing, 2012.
Zhang, W. L., Tian, Z. X., Zhang, N., and Li, X. Q.: Nitrate pollution of groundwater in Northern China, Agr. Ecosyst. Environ., 59, 223-231, 1996.

Zhang, Y., Tang, C., Song, X., and Li, F.: Behavior and fate of alkylphenols in surface water of the Jialu River, Henan Province, China, Chemosphere, 77, 559-565, 2009.

Zhang, Y., Song, X., Kondoh, A., Xia, J., and Tang, C.: Behavior, mass inventories and modeling evaluation of xenobiotic endocrine-disrupting chemicals along an urban receiving waste water river in Henan Province, China, Water Res., 45, 292-302, 2011.

Zhao, H., Zhang, J., Xie, D., Li, Y., Li, Y., Jia, H., and Wang, Y.: Temporal distribution regularity of water quality in Jialu River, J. Zhoukou Normal Univ., 22, 68-70, 2005. 